Artur Jach-Chrząszcz

\title{
Regulacja statusu prawnego potrianońskiej diaspory zamieszkującej państwa ościenne jako istotny cel polityki zagranicznej Węgierskiego Forum Demokratycznego w latach 1990-1994
}

\section{Wprowadzenie}

Schyłek lat 80. ubiegłego wieku w Europie Środkowej i Wschodniej zapoczątkował liczne zmiany polityczne, których następstwa z łatwością można obserwować do dziś. Po trwającym blisko pół wieku monopolu partii komunistycznych, władzę w poszczególnych krajach Europy Środkowej i Wschodniej zaczęły przejmować nowo powstałe partie polityczne, które stanęły przed niezwykle odpowiedzialnym zadaniem ukształtowania przyszłości suwerennych państw. Obok natychmiastowych działań mających na celu przeprowadzenie gospodarki od centralnie planowanej do rynkowej, władze każdego z tych państw musiały już na początku swoich rządów stworzyć nowe lub zmodyfikować dotychczasowe regulacje prawne na szczeblu międzynarodowym. Jednym z najważniejszych celów polityki zagranicznej poszczególnych rządów było ukształtowanie podstaw prawnych dla stosunków międzynarodowych pomiędzy suwerennymi państwami po transformacji ustrojowej. Z perspektywy węgierskiej dyplomacji jednym z najtrudniejszych elementów negocjacji prowadzonych z państwami ościennymi była regulacja praw i obowiązków zamieszkujących tam węgierskich mniejszości narodowych.

Celem niniejszej pracy jest analiza dążeń pierwszego rządu węgierskiego po transformacji ustrojowej mających na celu uregulowanie statusu prawnego potrianońskiej diaspory węgierskiej zamieszkującej państwa ościenne. Zanim podjęta zostanie wspomniana analiza, w pierwszej kolejności przedstawione zostanie polityczne tło historyczne, które ma na celu uwidocznienie czytelnikowi znaczenie i konsekwencje zmian etniczno-terytorialnych jakie powstały w następstwie podpisania traktatu w Trianon. Wprowadzenie to ułatwi zrozumieć powody, 
dla których pierwszy węgierski rząd po transformacji ustrojowej dążył poprzez wieloletnie negocjacje z przedstawicielami poszczególnych państw sąsiednich do wypracowania odpowiednich regulacji prawnych dla węgierskich mniejszości narodowych w ramach tworzonych układów o podstawach dobrosąsiedztwa i współpracy. Niniejszy tekst opiera się na węgiersko-, angielsko- i polskojęzycznych publikacjach naukowych, artykułach prasowych oraz materiałach internetowych, jak również na oryginalnych tekstach aktów prawnych.

\section{Polityczne tło historyczne w okresie międzywojennym i po drugiej wojnie światowej}

Zmiany etniczno-terytorialne, do jakich doszło na mocy traktatu w Trianon, stały się już na początku lat 20. ubiegłego wieku jednym z najważniejszych tematów politycznych poruszanych na Węgrzech. Starty gospodarcze powstałe w kraju w następstwie działań wojennych zwielokrotniła regulacja prawna wypracowana 4 czerwca 1920 roku w wersalskim pałacu Grand Trianon, w wyniku której Węgry utraciły znaczną część terytorium (z $325411 \mathrm{~km}^{2}$ do $\left.92963 \mathrm{~km}^{2}\right)^{1}$, jak również ludności² (z 20886487 do 7615117 osób) 3. Obok licznych sankcji, jakie zostały nałożone na Węgry (co później przełożyło się na trudności związane z rozwojem ekonomicznym państwa), należy wskazać na to, że wraz z redukcją terytorialną doszło do znacznego zmniejszenia eksploatowanego do paryskiej konferencji pokojowej majątku narodowego, do którego zaliczyć można między innymi dobrze prosperujące kopalnie, wyrobiska złota i srebra czy zakłady przemysłowe $e^{4}$.

Brak zgody na straty terytorialne, ludnościowe i majątkowe pogłębiało wśród węgierskiego społeczeństwa także poczucie niesprawiedliwości związanej ze skalą restrykcji, która okazała się nieporównywalnie większa względem Węgier aniżeli innych państw, wobec których orzekano w Trianon ${ }^{5}$. Odpowiedzią na niezadowolenie węgierskiego społeczeństwa była rewizjonistyczna polityka, którą 16 XI 1919 r. - nazajutrz po opuszczeniu Budapesztu przez rumuńskie wojska, zapoczątkował na placu Gellerta admirał Miklós Horthy ${ }^{6}$. Były dowódca floty austro-

\footnotetext{
J. Lőkkös, Trianon számokban: az 1910. évi magyar népszámlálás anyanyelvi adatainak elemzése a történelmi Magyarországon, Budapest 2000, s. 38-39.

2 Zgodnie z danymi za rok 1910.

3 B. Płonka, Straty terytorialne poniesione przez Wegry w wyniku dyktatu trianońskiego [2013], rcin.org.pl/Content/40229/WA51_57202_r2013-nr242_Prace-Geogr.pdf (3 V 2020).

4 B. Nagy, Van-e arany a magyar földben? [1998], www.termeszetvilaga.hu/kulonsz/k982/arany. html (3 V 2020).

5 A. Jach-Chrząszcz, Motyw Trianon w węgierskiej polityce historycznej po 1989 roku, Kraków 2020, s. 147-184.

6 J. Gergely, P. Pritz, A trianoni Magyarország: 1918-1945, Budapest 1998, s. 41-42.
} 
-węgierskiej, wzywając naród do pojednania, wzmocnił rozpoczęte jeszcze przed traktatem w Trianon działania określane mianem „białego terroru” (węg. fehérterror), mające na celu przede wszystkim wyeliminowanie wszelkich bezpośrednich powiązań z rewolucją komunistyczną i krótko funkcjonującą Węgierską Republiką Ludową w latach 1918-19197. Narastający antysemityzm, będący następstwem „białego terroru”, kryzys gospodarczy, a także próba odrestaurowania władzy na Węgrzech przez cesarza Karola I Habsburga (na Węgrzech - króla Karola IV) okazały się najpoważniejszymi wyzwaniami, przed jakimi stanął wybrany przez Zgromadzenie Narodowe 1 III 1920 r. regent Królestwa Węgier Miklós Horthy ${ }^{8}$. Oprócz powyższych trudna sytuacja węgierskiej diaspory w państwach sąsiednich potęgowała społeczne niezadowolenie spowodowane niekorzystnymi postanowieniami z Trianon. Obok strat terytorialnych oraz ludnościowych, nałożone na Węgry sankcje militarne uniemożliwiały rozwój węgierskiego sektora obronności. Był to jeden z głównych powodów, dla których regent zdecydował się ocieplić relacje z szefem włoskiego rządu Benito Mussolinim, z którym 5 IV 1927 r. Węgry podpisały traktat o przyjaźni ${ }^{9}$.

Współpraca przywódców o prawicowych poglądach i coraz częściej głoszone przez władze $w$ Budapeszcie postulaty rewizji postanowień $\mathrm{z}$ Trianon przyczyniły się również do nawiązania współpracy z wybranym w styczniu $1933 \mathrm{r}$. kanclerzem Niemiec Adolfem Hitlerem. Zacieśnienie stosunków węgierskich władz z Hitlerem i Mussolinim przyniosło pożądany efekt - możliwość rewizji granic terytorialnych po traktacie w Trianon 2 XI $1938 \mathrm{r}$. W wyniku pierwszego arbitrażu wiedeńskiego Węgry odzyskały zachodnią część Rusi Podkarpackiej z Użhorodem (węg. Ungvár), a także południową część Słowacji z Koszycami (węg. Kassa $)^{10}$. Doprowadzenie do realizacji jednego z najważniejszych postulatów, jakie Horthy wysuwał obejmując władzę na Węgrzech, umocniło jego władzę i zwiększyło poparcie dla niego wśród węgierskiego społeczeństwa. Możliwość przeprowadzenia kolejnej rewizji terytorialnej przez Włochy i Niemcy sprawiła, że węgierskie władze - pomimo konsekwencji w postaci wzrostu zależności od tych państw - zaczęly dążyć do przeprowadzenia kolejnego arbitrażu. Ten miał miejsce 30 VIII 1940 r., kiedy Węgry odzyskały północne ziemie Siedmiogrodu o powierzchni $43492 \mathrm{~km}^{2}$. Rosnące uzależnienie polityczne Węgier od III Rzeszy, które przełożyło się na poważne starty wśród narodowych formacji wojskowych

7 G. Bödők, Vörös és fehérterror Magyarországon (1919-1921) [2018], http://disszertacio.unieger.hu/54/4/Bodok_disszertacio.pdf (3 V 2020).

8 T. Dobszay, Tisztelt ház! A Magyar Országgyülések története 1848-1998, Budapest 1998, s. 116-117.

9 M. Szabó, A magyar királyi honvéd légierő: elméleti - technikai - szervezeti fejlődése és háborús alkalmazása 1938-1945, Budapest 1999, s. 10.

10 I. Deak, Hungary from 1918 to 1945, New York 1989, s. 30. 
(rozbicie 2. Armii Węgierskich Sił Zbrojnych ${ }^{11}$ ), a także kryzys gospodarczy, wywołały wątpliwości wśród węgierskiej elity rządzącej co do współpracy z Hitlerem. Pomimo faktu, że nie doszło do realizacji (operacja Margarethe ${ }^{12}$ ) planów Horthyego mających na celu przejście do koalicji antyhitlerowskiej, Węgry - na mocy podpisanego 10 II 1947 r. pokoju paryskiego - były sądzone jako sojusznik III Rzeszy. W konsekwencji, oprócz konieczności uregulowania reparacji wojennych, na kraj nałożono obowiązek zwrotu wszystkich terytoriów do stanu sprzed pierwszego arbitrażu wiedeńskiego ${ }^{13}$.

Pomimo niekorzystnych z perspektywy Węgier rozstrzygnięć, odzyskanie nawet na ten krótki czas - utraconych na mocy traktatu w Trianon terytoriów wraz z zamieszkującą je węgierskimi mniejszościami narodowymi pokazało społeczeństwu, iż decyzje polityczne podjęte w 1920 r. nie były ostateczne i niezmienne. Jednak okres następujący po zakończeniu drugiej wojny światowej skutecznie uniemożliwił jakiekolwiek próby ich rewizji, a także utrudnił poruszanie tematu Trianon w przestrzeni publicznej. W opinii Jacka Żołąźa proklamowana 8 IV 1949 r. Węgierska Republika Ludowa w zakresie polityki zagranicznej czy etnicznej charakteryzowała się całkowitym podporządkowaniem światowej polityce Związku Radzieckiego ${ }^{14}$. Ta z kolei opierała się na idei „braterstwa” z krajami sąsiednimi, co wiązało się z eliminowaniem czynników mogących prowadzić do nieporozumień - w tym przypadku dialogu na temat diaspory węgierskiej zamieszkującej owe „bratnie” państwa. Co prawda, János Kádár, który po rewolucji z 1956 r. został sekretarzem generalnym KC Węgierskiej Socjalistycznej Partii Robotniczej, poruszał kwestię węgierskich mniejszości narodowych podczas oficjalnych podróży dyplomatycznych do Rumunii i Czechosłowacji w 1958 r. Niemniej jednak polegało to raczej na zapewnieniach, że strona węgierska nie zamierza wysuwać roszczeń terytorialnych aniżeli na próbach podjęcia działań na rzecz ochrony interesów tych mniejszości ${ }^{15}$.

Prawdopodobnie najistotniejsze wydarzenie, które rzeczywiście się przełożyło na charakter polityki prowadzonej przez kolejne węgierskie partie polityczne po transformacji ustrojowej, miało miejsce na przełomie lipca i sierpnia $1975 \mathrm{r}$. podczas Konferencji Bezpieczeństwa i Współpracy w Europie (KBWE) w Helsinkach $^{16}$. Wypracowano wówczas porozumienie, zgodnie z którym Węgry wyrzekły

11 L. Zsigmondy, A 2. Magyar Hadsereg a Szovjetunió elleni háborúban 1942-1943, Székesfehérvár 1995.

12 G. Vargyai, J. Almási, Magyarország 1944: Német megszállás, Budapest 1994, s. 7-18.

13 I. Romsics, Az 1947-es párizsi békeszerződés, Budapest 2006.

14 J. Żołądź, Polityka zagraniczna współczesnych Węgier a kwestia mniejszości węgierskich w krajach Europy Środkowo-Wschodniej, „Wschodnioznawstwo” 2009, s. 215-232.

15 G. Balogh, Kádár és Trianon [2009], tortenelemportal.hu/2009/08/kadar-es-trianon/ (3 V 2020).

16 I. Romsics, Helyünk és sorsunk a Duna-medencében, Budapest 1996, s. 342. 
się wszelkich rewizjonistycznych roszczeń granicznych ${ }^{17}$. Podjęte w 1988 r. próby ochrony interesów węgierskiej mniejszości narodowej, zamieszkującej terytorium Siedmiogrodu, wobec polityki przesiedleń planowanej przez władze w Bukareszcie zapoczątkowały liczne protesty, które przyczyniły się do przemian ustrojowych mających miejsce w regionie zamieszkiwanym najliczniej przez węgierską mniejszość narodową. Wśród licznych założeń programowych, jakie węgierskie środowiska opozycyjne tworzyły z końcem lat osiemdziesiątych, niewątpliwie ważną rolę pełniła istota reprezentowania interesów węgierskich mniejszości narodowych zamieszkujących państwa sąsiadujące z Węgrami.

\section{Początki Węgierskiego Forum Demokratycznego i pierwsze demokratyczne wybory (25 III i 8 IV 1990 r.)}

Z początkiem 1985 r., kiedy to rozpoczął się proces przekształceń komunistycznego systemu Związku Radzieckiego, poszczególne środowiska opozycyjne wobec ówczesnych władz państwowych na terytorium Europy Środkowej i Wschodniej rozpoczęły formowanie struktur, które w niedalekiej przyszłości nie tylko uczestniczyły w kluczowych negocjacjach z przedstawicielami rządzących partii komunistycznych, ale również obejmowały w tych krajach władzę polityczną. Przykładem takiej partii na Węgrzech jest Węgierskie Forum Demokratyczne, którego początki datuje się na 27 IX 1987 r. Doszło wtedy w miejscowości Lakitelek $^{18}$ do spotkania blisko dwustu intelektualistów w celu wymiany poglądów. Zdarzenie to stało się na Węgrzech symbolem formowania w tym kraju systemu wielopartyjnego ${ }^{19}$.

Wydarzenia Jesieni Ludów zapoczątkowały negocjacje prowadzone przy Okrągłym Stole przez stronę rządzącą i opozycję w Polsce ${ }^{20}$, a niedługo później $\mathrm{w}$ podobnej formule do rozmów przystąpiła również strona węgierska w ramach Trójkątnego Stołu (węg. Ellenzéki Kerekasztal) ${ }^{21}$. Cechą wspólną wszystkich tych rozmów, które odbywały się w państwach uczestniczących w Jesieni Ludów, była możliwość zaistnienia czy też zdobycia popularności przez charyzmatycznych przedstawicieli strony opozycyjnej. Na Węgrzech takim liderem został József Antall - co potwierdzili uprawnieni do głosowania delegaci, którzy 21 X 1989 r.

17 G. Stokes, The Walls Came Tumbling Down: The Collapse of Communism in Eastern Europe, Oxford 1993, s. 209.

18 M. Elbert, A Rendszerváltás forgatókönyve: Dokumentumok 1989. június 13-július 17, Budapest 1999, s. 210.

19 S. Dobos, A lakiteleki találkozó (1987) [27 IX 2010], https://24.hu/tudomany/2010/09/27/alakiteleki-talalkozo-1987/ (3 V 2020).

20 B. Kaczorowski, Nowa encyklopedia powszechna PWN, Warszawa 2004, s. 153.

21 A. Richter, Ellenzéki kerekasztal, Budapest 1990. 
niemal jednogłośnie zdecydowali, iż to on zostanie liderem partii mającej realne szanse na objęcie władzy drogą demokratycznych wyborów do Zgromadzenia Narodowego ${ }^{22}$.

Największymi rywalami Węgierskiego Forum Demokratycznego (MDF) w walce o większość parlamentarną były liberalny Związek Wolnych Demokratów (SZDSZ), a także wywodząca się z reformatorskiego skrzydła Węgierskiej Socjalistycznej Partii Robotniczej (MSZMP) Węgierska Partia Socjalistyczna (MSZP). Przy frekwencji wynoszącej w pierwszej turze (25 III 1990 r.) 65,11\% i w drugiej turze (8 IV 1990 r.) 45,51\% największe poparcie otrzymało MDF, które - zdobywszy 44,49\% ogółu głosów - zapewniło sobie 164 z 386 miejsc w Zgromadzeniu Narodowym ${ }^{23}$. Węgierskie Forum Demokratyczne, tworząc koalicję z Chrześcijańsko-Demokratyczną Partią Ludową (KDNP) i Węgierską Partią Drobnych Rolników (FKGP), uzyskało większość parlamentarną, co umożliwiło utworzenie rządu, na czele którego stanął József Antall.

\section{Polityka zagraniczna i kwestie mniejszości narodowych}

Węgierskie Forum Demokratyczne, formując pierwszy po transformacji ustrojowej rząd, swoimi decyzjami czy też postępowaniem politycznym rozpoczęło etap, do którego w przyszłości wszystkie partie polityczne sprawujące władzę na Węgrzech będą musiały się odnieść. Oczywiście, bez względu na różnice dzielące ideologie największych węgierskich partii obecnych na scenie politycznej w latach 90. panowała właściwie jednomyślność co do dążeń umożliwiających przystąpienie Kraju do Unii Europejskiej czy NATO. W kolejnych latach, pomimo zachodzących zmian politycznych, działania w tym kierunku były kontynuowane.

Przeciwieństwo powyższego może stanowić stosunek poszczególnych partii politycznych wobec sytuacji węgierskich mniejszości narodowych zamieszkujących w państwach ościennych. W tym przypadku podejście największej wówczas partii opozycyjnej (SZDSZ) znacznie się różniło od stanowiska Węgierskiego Forum Demokratycznego. Stosunek nowo wybranego premiera do diaspory węgierskiej można było dostrzec już w czerwcu 1990 r., kiedy to oświadczył: „w rozumieniu obowiązującego na Węgrzech prawa powszechnego jako przywódca wszystkich obywateli węgierskich i szef rządu tego dziesięciomilionowego kraju w sensie moralnym i emocjonalnym chciałbym być premierem 15 milionów Węgrów" (węg. Törvényes értelemben, a magyar közjog alapján minden magyar állampolgárnak, ennek a tízmilliós országnak a kormányföjeként - lélekben, érzés-

22 J. Debreczeni, A miniszterelnök. Antall József és a rendszerváltozás, Budapest 1998, s. 212.

23 P. Tibor, Mikor kezdték listázni a szimpatizáns választókat? [8 IV 2018], www.magyarnemzet. hu/archivum/billego-korzet/mikor-kezdtek-listazni-a-szimpatizans-valasztokat-3846616/ (3 V 2020). 
ben 15 millió magyar miniszterelnöke kívánok lenni $\left.{ }^{24}\right)$. Słowa te sprawiły, że Antall w pamięci Węgrów zapisał się jako „premier 15 milionów Węgrów”25. Rzecz jasna takie wystąpienie wzbudziło obawy władz państw ościennych. Wszak taka wypowiedź najważniejszej osoby w państwie mogła otworzyć nowy rozdział węgierskiej polityki zagranicznej, podważając tym samym ustalenia sformułowane podczas KBWE w 1975 r. w Helsinkach. Największe zaniepokojenie wyraziły władze Rumunii i Czechosłowacji, a więc państw najliczniej zamieszkiwanych przez węgierską mniejszość narodową.

Z jednej strony wystąpienie premiera wzmocniło tożsamość narodową węgierskiej diaspory, z drugiej jednak przyczyniło się do pewnych trudności na polu dyplomatycznym. Celem nowo wybranego rządu i, przede wszystkim zadaniem, węgierskiego Ministerstwa Spraw Zagranicznych było uregulowanie statusu prawnego węgierskich mniejszości narodowych w państwach sąsiadujących z Węgrami. Zgodnie z wynikami spisów powszechnych przeprowadzonych w latach 1989-1992 wykazano liczebność mniejszości narodowych w państwach ościennych z Węgrami: 1624000 węgierskiej mniejszości zamieszkiwało Rumunię (7,1\% ogółu mieszkańców Rumunii), Słowację 567296 (10,8\%), Serbię 343942 (3,5\%), Ukrainę 163111 (0,3\%), Chorwację 22355 (0,5\%), Słowenię 8503 $(0,4 \%)$ oraz Austrię $33459(0,4 \%)^{26}$.

Jednym z najważniejszych powodów, dla których węgierski rząd dążył do wypracowania regulacji związanych ze statusem prawnym liczącej ponad 2,5 miliona węgierskiej diaspory zamieszkującej państwa sąsiadujące z Węgrami, była dysproporcja przywilejów występująca pomiędzy państwami postkomunistycznymi a zachodnimi ${ }^{27}$. Argumentem umożliwiającym kierowanie wniosków, które mogłyby przyczynić się do przyznania dodatkowych praw węgierskim mniejszościom narodowym zamieszkującym państwa ościenne była zatem szansa odwoływania się do standardów zachodnich, a także wsparcie, na jakie węgierski rząd mógł liczyć ze strony instytucji międzynarodowych regulujących prawa mniejszości narodowych ${ }^{28}$.

Zanim jeszcze Ukraina, na terytorium której zamieszkiwała węgierska diaspora, odzyskała niepodległość, prezydent Árpád Göncz - dzięki utrzymywaniu bliskich relacji z tym krajem - przyczynił się do uregulowania praw, jakie otrzymała

24 E. Marinovich, Mit üzen Antall József a XXI. század fiatalságának? [12 II 2016], http://www. antalljozsef.igytortent.hu/component/content/article/19-az-antalli-orokseg/87-mit-uzenantall-jozsef-a-xxi-szazad-fiatalsaganak.html (3 V 2020).

25 „15 millió magyar miniszterelnöke” - emlékezés Antall Józsefröl, https://arhiv.minap.hu/ content/15-millio-magyar-miniszterelnoke-emlekezes-antall-jozsefrol (3 V 2020).

26 L. Gyurgyík, A határon túli magyarok számának alakulása az 1990-es években [2009], http:// www.matud.iif.hu/05feb/03.html (3 V 2020).

27 J. Żołądź, op.cit.

28 A. Jach-Chrząszcz, op.cit., s. 218. 
węgierska mniejszość narodowa zamieszkująca ten kraj. Szczególnie ważna była reforma szkolnictwa, która umożliwiła na terytorium Zakarpacia ukończenie pełnego węgierskojęzycznego systemu edukacyjnego - od przedszkola po szkolnictwo wyższe ${ }^{29}$. Układ o podstawach dobrosąsiedztwa i współpracy między Republiką Węgierską a Ukrainą został podpisany 6 XII 1991 r. przez Łeonida Krawczuka i Józsefa Antalla ${ }^{30}$.

Kwestie szkolnictwa oraz rozwoju gospodarczego czy kulturalnego były istotnym elementem traktatu o przyjaźni i współpracy, który Republika Węgier zawarła z Republiką Słowenii 1 XII 1992 r. ${ }^{31}$. Dwa tygodnie później, 16 XII 1992 r., podpisany został traktat o przyjaznych stosunkach i współpracy Węgier z Chorwacją ${ }^{32}$, którego postanowienia zostały rozszerzone o kolejne artykuły 5 IV $1995 \mathrm{r}$. (dwustronna umowa o ochronie węgierskiej mniejszości w Republice Chorwackiej i chorwackiej mniejszości w Republice Węgierskiej) ${ }^{33}$.

Proces rozpadu Czechosłowacji i objęcie urzędu premiera Słowacji przez lidera narodowo-konserwatywnej Partii Ludowej - Ruch na rzecz Demokratycznej Słowacji Vladimíra Mečiara uniemożliwiły przedstawicielom MDF osiągnięcie kompromisu w zakresie uregulowania statusu prawnego węgierskiej mniejszości narodowej zamieszkującej ponad $10 \%$ terytorium tego kraju. Z podobnymi utrudnieniami spotkało się węgierskie MSZ w trakcie negocjacji z Rumunią, której władze zdecydowały się obserwować przebieg negocjacji i końcowe ustalenia między Węgrami a innymi państwami sąsiednimi. Stabilne funkcjonowanie rządu, które mogłoby się przełożyć na nieprzerwaną realizację założeń programowych, utrudniały coraz gorsze wskaźniki gospodarcze, jak również rywalizacja wewnątrzpartyjna (spór na linii Antall-Torgyan czy zakłócające negocjacje ze Słowacją i Rumunią kontrowersyjne poglądy Istvána Csurki), którą pogłębiła 12 XII 1993 r. śmierć lidera MDF i pierwszego premiera demokratycznych Węgier Józsefa Antalla. Péter Boross, który obowiązki szefa rządu sprawował do 15 VII 1994 r., nie był w stanie uchronić koalicji przed utratą władzy, którą - wraz z własną wizją rozwoju polityki zagranicznej państwa - przejęła koalicja MSZP-SZDSZ.

29 Ibidem, s. 136.

30 R. Cowen, Central and Eastern Europe. The Challenge of Transition, New York 1993, s. 134.

31 Egyezmény a Magyar Köztársaságban élő szlovén nemzeti kisebbség és a Szlovén Köztársaságban élö magyar nemzeti közösség különjogainak biztositásáról, adattar.adatbank.transindex.ro/ ketoldalu/ksz-sl-h.htm (3 V 2020).

32 Szerzõdés a Magyar Köztársaság és a Horvát Köztársaság között a baráti kapcsolatokról és együttmûködésrõl, adattar.adatbank.transindex.ro/Horvatorszag/d921216ahu.htmv (3 V 2020).

33 1995. évi XLVII. törvény; A Magyar Köztársaság és a Horvát Köztársaság között Budapesten, 1992. december 16-án aláírt, a baráti kapcsolatokról és együttmûködésrõl szóló Szerzõdés kihirdetésérõl, adattar.adatbank.transindex.ro/Horvatorszag/d950405a.htm (3 V 2020). 


\section{Zakończenie}

András Sütő, pisarz i przedstawiciel węgierskiej diaspory zamieszkującej Rumunię, w dniu pogrzebu Antalla powiedział przed węgierskim parlamentem, iż żadna osoba, która obejmie urząd premiera po Antallu, nie zrobi więcej dla węgierskich mniejszości narodowych, aniżeli zrobił szef pierwszego rządu po transformacji ustrojowej ${ }^{34}$. József Antall otworzył nowy rozdział węgierskiej historii, realizując politykę narodowościową, która polegała między innymi na wdrażaniu nowych regulacji prawnych wobec mniejszości narodowych w państwach sąsiadujących z Węgrami.

Wprowadzenie na początku lat 90. do ustawy zasadniczej zapisu mówiącego o odpowiedzialności Republiki Węgierskiej za los Węgrów mieszkających poza granicami kraju, został jeszcze bardziej rozszerzony w 2011 r. przez rządzącą już trzecią kadencję z rzędu koalicję Fidesz-KDNP. Kontynuowanie tej idei obecnie może świadczyć o tym, jak ważne było podjęcie niezbędnych działań oraz podpisanie układów o dobrosąsiedztwie i współpracy z poszczególnymi państwami sąsiednimi, których postanowienia znalazły bezpośrednie przełożenie na zwiększenie czy też unormowanie praw, jakie otrzymały węgierskie mniejszości narodowe. Te - jak wykazała analiza przedstawiona w niniejszej pracy - były dla sprawujących władzę ważne tak naprawdę od czasu, kiedy tylko ta kwestia zaistniała. Regent Miklós Horthy dążył do rewizji postanowień z Trianon. W okresie demokracji ludowej, pomimo starań uniemożliwiających prowadzenie dyskursu na temat mniejszości narodowych, doszło w 1975 r. do porozumienia, którego postanowienia mają moc prawną do dziś.

Zwycięstwo Węgierskiego Forum Demokratycznego z Antallem na czele w pierwszych demokratycznych wyborach do Zgromadzenia Narodowego pozwoliło zbudować filary norm, do których później musiały ustosunkować się kolejne partie polityczne sprawujące władzę na Węgrzech. Antall w 1991 r. osobiście doglądał podpisania międzypaństwowego układu o podstawach dobrosąsiedztwa i współpracy między Republiką Węgierską i Ukrainą, a także rok później traktatu o przyjaźni i współpracy z Republiką Słowenii i Chorwacji. Regulacje umożliwiające wprowadzenie przywilejów w używaniu języka węgierskiego w szkolnictwie, administracji, sądownictwie czy w ramach organizacji struktur administracyjno-terytorialnych nie zostały wdrożone w trakcie rządów MDF w dwóch krajach najliczniej zamieszkiwanych przez węgierską diasporę - w Rumunii oraz w Czechosłowacji (po 1993 r. na Słowacji). Jak już zostało zauważone powyżej, stało się tak z powodu nieskutecznej polityki zagranicznej prowadzonej przez węgierski MSZ przy jednoczesnym oporze stawianym przez powyższe państwa. Ponadto,

34 G. Csóti, Nemzetpolitikai alapvetés [2018], https://antalljozsef25.hu/emlektoredekek/csotigyorgy/741-nemzetpolitikai-alapvetes (3 V 2020). 
z uwagi na liczne czynniki zewnętrzne, takie jak utrata lidera czy wewnętrzne rozłamy, a także niezadowolenie społeczeństwa sytuacją gospodarczą nastąpiło wstrzymanie negocjacji, które ostatecznie ukończył koalicyjny rząd MSZP-SZDSZ z Gyulą Hornem na czele ${ }^{35}$.

Biorąc pod uwagę czas, w którym powyższe działania MDF wykonywało na rzecz węgierskich mniejszości zamieszkujących państwa sąsiadujące z Węgrami, trzeba przyznać zauważalny wkład na rzecz podniesienia ich statusu. Utworzenie umów o dobrym sąsiedztwie z większością państw sąsiadujących z Węgrami wyznaczyło pewne standardy, do których kolejne władze mogły w przyszłości się odnieść. Jednak, jak pokazały późniejsze decyzje wyborców, obok oczekiwań mających na celu realizację działań umożliwiających podniesienie statusu mniejszości węgierskiej zamieszkującej w sąsiednich krajach, kluczowy okazał się czynnik ekonomiczny i tym samym dążenia do zmiany sytuacji gospodarczej w kraju.

\author{
Abstract \\ Artur Jach-Chrząszcz \\ Regulation of the legal status of the post-Trianon diaspora \\ inhabiting neighboring countries as a vital goal \\ of the Hungarian Democratic Forum foreign policies \\ between 1990 and 1994
}

The political transformation that started at the end of the 80s required the newly elected governments of both Central and Eastern Europe to modify and - in some cases - even develop from scratch legal regulations allowing for a proper functioning of such countries in a completely new political reality. By starting with the presentation of the political Trianon discourse in the inter-war and people's democracy periods, the author is going to analyze the attempts of the very first Hungarian government (led by the Hungarian Democratic Forum between 1990 and 1994) after the political transformation that aimed at regulating the legal status of diaspora living in countries neighboring with Hungary.

Keywords: Hungarian Democratic Forum, Treaty of Trianon, National minority, Foreign policy, Hungary

35 Umowa o dobrym sąsiedztwie i przyjaznej współpracy ze Słowacją została podpisana 19 III 1995 r., a Umowa o wzajemnym zrozumieniu, przyjaźni i dobrym sąsiedztwie z Rumunią 16 IX $1996 \mathrm{r}$. 


\section{References}

„15 millió magyar miniszterelnöke” - emlékezés Antall Józsefről, https://arhiv. minap.hu/content/15-millio-magyar-miniszterelnoke-emlekezes-antalljozsefrol.

Balogh, G., Kádár és Trianon, tortenelemportal.hu/2009/08/kadar-es-trianon/.

Bödők, G., Vörös és fehérterror Magyarországon (1919-1921), http://disszertacio. uni-eger.hu/54/4/Bodok_disszertacio.pdf.

Cowen, R., Central and Eastern Europe. The Challenge of Transition, New York 1993.

Csóti, G., Nemzetpolitikai alapvetés, https://antalljozsef25.hu/emlektoredekek/ csoti-gyorgy/741-nemzetpolitikai-alapvetes.

Deak, I., Hungary from 1918 to 1945, New York 1989.

Debreczeni, J., A miniszterelnök. Antall József és a rendszerváltozás, Budapest 1998.

Dobos, S., A lakiteleki találkozó (1987), https://24.hu/tudomany/2010/09/27/a-lakiteleki-talalkozo-1987.

Dobszay, T., Tisztelt ház! A Magyar Országgyülések története 1848-1998, Budapest 1998.

Egyezmény a Magyar Köztársaságban élő szlovén nemzeti kisebbség és a Szlovén Köztársaságban élö magyar nemzeti közösség különjogainak biztositásáról, adattar.adatbank.transindex.ro/ketoldalu/ksz-sl-h.htm.

Elbert, M., A Rendszerváltás forgatókönyve: Dokumentumok 1989. június 13-július 17, Budapest 1999.

Gergely, J., Pritz P., A trianoni Magyarország: 1918-1945, Budapest 1998.

Gyurgyík, L., A határon túli magyarok számának alakulása az 1990-es években, www.matud.iif.hu/05feb/03.html.

Jach-Chrząszcz, A., Motyw Trianon w wegierskiej polityce historycznej po 1989 roku, Kraków 2020.

Kaczorowski, B., Nowa encyklopedia powszechna PWN, Warszawa 2004.

Lőkkös, J., Trianon számokban: az 1910. évi magyar népszámlálás anyanyelvi adatainak elemzése a történelmi Magyarországon, Püski, Budapest 2000.

Nagy, B., Van-e arany a magyar földben?, www.termeszetvilaga.hu/kulonsz/k982/ arany.html.

Płonka, B., Straty terytorialne poniesione przez Wegry w wyniku dyktatu trianońskiego, rcin.org.pl/Content/40229/WA51_57202_r2013-nr242_Prace-Geogr.pdf.

Richter, A., Ellenzéki kerekasztal, Budapest 1990.

Romsics, I., Az 1947-es párizsi békeszerződés, Budapest 2006.

Romsics, I., Helyünk és sorsunk a Duna-medencében, Budapest 1996.

Stokes, G., The Walls Came Tumbling Down: The Collapse of Communism in Eastern Europe, Oxford 1993. 
Szabó, M., A magyar királyi honvéd légierő: elméleti - technikai - szervezeti fejlődése és háborús alkalmazása 1938-1945, Budapest 1999.

Szerzõdés a Magyar Köztársaság és a Horvát Köztársaság között a baráti kapcsolatokról és együttmûködésrõl, adattar.adatbank.transindex.ro/Horvatorszag/ d921216ahu.htmv.

Tibor, P., Mikor kezdték listázni a szimpatizáns választókat?, www.magyarnemzet. hu/archivum/billego-korzet/mikor-kezdtek-listazni-a-szimpatizans-valasztokat-3846616/.

Vargyai, G., Almási, J., Magyarország 1944: Német megszállás, Budapest 1994.

Zsigmondy, L., A 2. Magyar Hadsereg a Szovjetunió elleni háborúban 1942-1943, Székesfehérvár 1995.

Artur Jach-Chrząszcz - dr politologii, prezes Zarządu European Foundation for Cooperation and Science. ORCID: 0000-0003-3248-4727 